\title{
Arbitration of Investor-Broker Disputes
}

The author analyzes the function of arbitration clauses in securities brokerage agreements and the enforceability of such clauses against investors seeking to litigate their claims against stockbrokers. After questioning the desirability of arbitration as a forum for resolving disputes in this area, the author considers tactical means by which the investor can avoid arbitration.

Securities regulation is public law, infusing broad policy considerations into the essentially contractual milieu of the securities industry. Nowhere is the public character of the securities laws more evident than in their nonwaiver provisions; each of the six acts under the jurisdiction of the Securities and Exchange Commission ${ }^{1}$ contains a provision ${ }^{2}$ declaring void as a matter of law all contracts which purport to waive compliance with that act. ${ }^{3}$

Although the language of these provisions may appear to limit thein to problems of compliance, it is now clear that they prohibit waiver of causes of action created by the securities laws, whether express $^{4}$ or implied. ${ }^{5}$ This approach is consistent with the central goal of the federal securities laws-protecting the investor. ${ }^{\circ}$ The individual investor signs instruments waiving rights of action for noncompliance because he lacks both the sophistication and the bargaining power to have such provisions excised.?

1. Securities Act of 1933,15 U.S.C. $\$ \S 77 a-77 a a$ (1970) [hereinafter referred to as Securities Act]; Trust Indenture Act of 1939, 15 U.S.C. \$\$77aaa-77bbbb (1970); Securities Exchange Act of 1934, 15 U.S.C. $\$ \S 78 a-78$ hh (1970 \& Supp. V 1975) [hereinafter referred to as Exchange Act]; Public Utility Holding Company Act of 1935, 15 U.S.C. $\$ \$ 79$ to $79 \mathrm{z}-6$ (1970); Investment Company Act of 1940 , 15 U.S.C. $\$ \$ 80 \mathrm{a}-1$ to -52 (1970); Investment Advisers Act of 1940, 15 U.S.C. $\$ \$ 80 \mathrm{~b}-1$ to -21 (1970).

2. Securities Act $\$ 14,15$ U.S.C. $\$ 77 \mathrm{n}$ (1970); Trust Indenture Act $\$ 327,15$ U.S.C. \$ 77aaaa (1970); Exchange Act $\$ 29(\mathrm{a}), 15$ U.S.C. $\$ 78 \mathrm{cc}(\mathrm{a})$ (1970); Public Utility Holding Company Act $\$ 26(a), 15$ U.S.C. $\$ 79 z(a)$ (1970); Investment Company Act $\$ 47(a), 15$ U.S.C. $\$ 80 a-46$ (a) (1970); Investment Advisers Act $\$ 215(\mathrm{a})$, 15 U.S C. $\$ 80 b-15(a)(1970)$.

3. The language used in the six nonwaiver provisions is virtually identical. Section 29(a) of the Exchange Act is representative:

Any condition, stipulation, or provision binding any person to waive compliance with any provision of this chapter or of any rule or regulation thereunder, or of any rule of an exchange required thereby shall be void.

15 U.S.C. \$ $78 \mathrm{cc}(\mathrm{a})(1970)$.

4. Wilko v. Swan, 346 U.S. 427 (1953).

5. Starkman v. Seroussi, 377 F. Supp. 518 (S.D.N.Y. 1974).

6. See United Hous. Found'n, Inc. v. Forman, 421 U.S. 837 (1975); Exchange Act § 2, 15 U.S.C. \$ 78b (1970 \& Supp. V 1975).

7. See, e.g., Scherk v. Alberto-Culver Co., 417 U.S. 506, 525-26 (1974) (Doug* 
In Wilko v. Swan, ${ }^{8}$ the Supreme Court held that an arbitration clause in a inargin account agreement between an investor and a brokerage firn constituted an inpermissible waiver of the investor's right to a judicial forum for the disposition of his claims arising under the Securities Act. Wilko dealt with the common practice in the securities industry of requiring retail customers to agree to arbitration of disputes arising from the investor-broker relationship. ${ }^{9}$ Despite Wilko, however, the practice has persisted; arbitration clauses are widely used by the major stock exchange firms in their margin and cash account agreements. ${ }^{10}$ The securities agreement that individual investors most frequently enter into-the contract for brokerage servicesalmost invariably contams a waiver in the form of an arbitration clause. The broker's arbitration clause has persisted largely because of the narrowness of the Wilko holding; by its terms it applies only to claims based on securities laws violations. Thus, the clause may be lawfully utilized by brokers potentially faced with other types of claims, as well as those faced with claims only arguably based on the securities laws.

The removal of many elements of the investor-broker relationship from the purview of arbitration highlights the conflict between the policy favoring arbitration, as set forth in the Federal Arbitration Act, ${ }^{11}$ and the policy of preserving rights under the securities laws from waiver by private contract. This conflict is reflected in the difficulties that courts have encountered in attempting to apply Wilko to varying factual situations. These difficulties have in turn elimimated much of the speed, simplicity, and efficiency which the arbitration forum ostensibly provides for the resolution of disputes; the arbitration clause functions mainly to generate dilatory procedural skirmishes that significantly complicate securities litigation. This Comment will analyze the substantive arbitrability of the disputes which arise between investors and their stockbrokers and will consider the efficacy of arbitration as a means of dispute resolution in the retail securities industry.

las, J., dissenting). But see Vernon v. Drexel Burnham \& Co., 52 Cal. App. 3d 706, 125 Cal. Rptr. 147 (1975) (rejecting investor's argument that broker's arbitration clause is unenforceable as adhesion contract).

8. 346 U.S. 427 (1953).

9. For the text of an arbitration clause in common use by brokerage firms, see text accompanying note 30 infra.

10. See Statement of J. Robert Lunney (Sept. 27, 1967), reprinted in NEw YoRK Chamber of Commerce, The Disputed Transaction: How Arbitration Is Used in THE SeCURITIEs Industry 44-45 (1967) [hereinafter cited as New York CHAMBer of Commerce]. See also Securities and Exchange Commission, Report of Special Study of Securtites Markets, H.R. Doc. No. 95, 88th Cong., 1st Sess., ch. 3, at 390-91 (1963) [hereinafter cited as SEC SPECIAL STUDY].

11. 9 U.S.C. $\$ \$ 1-14$ (1970). 


\section{Securities Broker-Dealers aNd Arbitration}

\section{A. Arbitration and the Self-Regulation of the Securities Industry}

Arbitration has long played a key role in the settlement of disputes on securities exchanges, ${ }^{12}$ and constitutes an integral part of the "selfregulation" of the securities industry. The rationale offered to support comprehensive utilization of a private form of dispute resolution is that the voluine of transactions on the exchanges could generate so inany disputes that vast sums of working capital would be tied up in protracted litigation if the industry had to depend on the courts. ${ }^{13}$ The constitutions of the New York, American, and Pacific Stock Exchanges, therefore, all contain provisions requiring their members to arbitrate any dispute with another member of the exchange. ${ }^{14}$ This intraexchange system of arbitration received a measure of approval from Congress; the nonwaiver section of the Exchange Act is inade inapplicable to "action taken by the authorities of [any self-regulatory organization] to settle disputes between its members or participants." ${ }^{15}$ This provision has been held to exempt arbitration provisions in stock exchange constitutions from the nonwaiver section of the Act. ${ }^{10}$

Each of the exchanges also provides an arbitration forum for disputes between members and nonmeinbers, principally claiuns by investors against member brokerage firms. The provisions for arbitration of noninember claims are extensions of this self-regulation scheme and operate within the same formal structure as the provisions for arbitration of intra-industry disputes. ${ }^{17}$ A nonmember investor can demand

12. See Stone, Justice Weighs Bulls and Bears, 7 ARB. J. (n.s.) 79 (1952).

13. See Jacquin, Arbitration in Action on Wall Street, 1 ARB. J. (n.s.) 261 (1946). Critics of the present structure of the securities industry, however, view the exchanges' arbitration procedures as an effort to prevent public disclosure of questionable industry practices. See generally R. Nex, The WALI StReEt GANG (1974).

14. American Stock Exchange Constitution art. VIII, \& 1, reprinted in 2 AM. STOCK EX. GuIDE (CCH) I 9062; New York Stock Exchange Constitution art. VIII, $\$ \S 1,5$, reprinted in 2 NYSE GUIDE $(\mathrm{CCH})$ กा 1351, 1355; Pacific Coast Stock Exchange Constitution art. XII, $\S 1$, reprinted in PAC. STOCK EX. GUIDE (CCH) $\pi 1801$. Also, the Board of Governors of the National Association of Securities Dealers (NASD) has adopted a Code of Arbitration Procedure requiring members of that organization to submit claims against fellow members to arbitration. NASD Manual (CCH) गी 3701-40.

15. Exchange Act $\$ 28(\mathrm{~b}), 15$ U.S.C. $\$ 78 \mathrm{bb}(\mathrm{b})$ (Supp. V 1975).

16. Axelrod \& Co. v. Kordich, Victor \& Neufeld, 451 F.2d 838 (2d Cir. 1971); Brown v. Gilligan, Will \& Co., 287 F. Supp. 766 (S.D.N.Y. 1968).

17. American Stock Exchange Constitution art. VIII, $\$ 1$, reprinted in 2 AM. STOCK Ex. Guide (CCH) .T 9062; New York Stock Exchange Constitution art. VIII, $\$ \S 1,6$, reprinted in 2 NYSE GuIDE (CCH) ITT 1351, 1356; Pacific Stock Exchange Constitution art. XII, $\$ 2$, reprinted in PAC. STOCK Ex. GuIDE (CCH) $\pi 1806$. 
arbitration of his disputes with member firms, whether or not his customer's agreement contains an arbitration clause. ${ }^{18}$ The exchanges also provide for arbitration at the member's instance where the nonmember has signed an enforceable arbitration agreement covering the disputed transaction. ${ }^{19}$ Arbitration may be instituted by the broker against the customer, or may result from a broker's motion for a stay pending arbitration in response to a customer's lawsuit.

The involvement of nonmembers in exchange arbitration has provoked considerable criticism of the structure of the proceedings and the background and orientation of the arbitrators. Although the New York Stock Exchange, for example, allows investors the opportunity to choose from two separate panels of arbitrators, both are heavily oriented toward the industry: a Board of Arbitration composed entirely of members and allied members (principally officers of member firms), and a mixed panel consisting of members of the brokerage community and persons from outside the industry. ${ }^{20}$ This arrangement may well further the self-regulation goal of the stock exchanges, but it does little to promote confidence in the arbitration process among the investing public; investors are understandably suspicious of a forum in which claims against brokerage houses are ordinarily adjudicated by stockbrokers. The consequence is strenuous resistance to exchange arbitration of customers' claims; where arbitration nevertheless proceeds and results in an award adverse to the investor, attacks on the validity of the award are not uncommon. ${ }^{21}$ While Wilko renders certain claims nonarbitrable, the brokers' arbitration clause retaims vital-

18. In theory, the exchanges are not obligated to permit a nonmember to utilize their constitutional provisions allowing arbitration instituted by nonmembers. See New York Stock Exchange Constitution art. VIII, $\$ 7$, reprinted in 2 NYSE GUIDE (CCH) II 1357, authorizing the Board of Directors of the New York Stock Exchange to decline permission for the use of the arbitration facilities "in any case." In practice, however, the New York Stock Exchange rarely, if ever, refuses to arbitrate a properly submitted claim against a member firm. See E. BRodsky, Guide to Securrties LITIGation 296 (1974).

19. Annerican Stock Exchange Constitution art. VIII, \$§ 1, 2(c), reprinted in 2 Aм. Stock Ex. Guide (CCH) ITा 9062-63; New Yolk Stock Exchange rule 481, reprinted in 2 NYSE GuIDE (CCH) \I 2481; Pacific Stock Exchange Constitution art. XII, § 2, reprinted in PAC. Stock Ex. GuIDE (CCH) đI 1806.

20. New York Stock Exchange Constitution art. VIII, § 4, reprinted in 2 NYSE GUIDE (CCH) TाT 1354, 1356. The arbitration panels of the American Stock Exchange have a similarly high degree of securities industry representation; of the three panels from which arbitrators are drawn, one is composed solely of members, one of nonmembers engaged in the securities industry, and one of arbitrators from outside the industry. American Stock Exchange Arbitration Rules 601-02, reprinted in 2 AM. STOCK Ex. GUme (CCH) IIT 9541.42.

21. Sce, e.g., Sobel v. Hertz, Warner \& Co., 469 F.2d 1211 (2d Cir. 1972); Arietta v. Paine, Webber, Jackson, \& Curtis, Inc., 59 Cal. App. 3d 322, 130 Cal. Rptr. 534 (2d Dist. 1976). 
ity in areas not covered by the Wilko decision, or where the applicability of Wilko is in doubt.

Although exchange arbitration is generally justified by invocation of the self-regulation talisman, ${ }^{22}$ the mechanisms for oversight of the self-regulatory process by the SEC are generally inapplicable to the arbitral process. Section 6 of the Exchange Act ${ }^{23}$ sets forth procedural standards for exchange hearings on membership applications and disciplimary sanctions and provides for limited SEC review of such proceedmgs; section $19^{24}$ requires self-regulatory organizations to notify the SEC of "any final disciplinary sanction" against a member or any denial of participation in the organization, and authorizes administrative review of such actions. Although the Supreme Court has held that exchange rules providing for arbitration of disputes between member firms and their employees are not the sort of self-regulatory rules subject to Commission oversight, ${ }^{25}$ that decision was based on the premise that the resolution of such in-house disputes is not sufficiently related to investor protection to bring the rules within the ambit of sections 6 and 19 of the Act. ${ }^{28}$ The rules concerning arbitration of nonmember disputes would thus appear to be properly subject to SEC review, since they bear directly on investor protection. An analysis of the changes wrought by the Securities Acts Amendments of $1975^{27}$ supports this interpretation; in an effort to overhaul the system of self-regulation, Congress broadly extended SEC authority over exchange rulemaking and quasi-adjudicatory procedures. The amendments were, in part, designed to restore the government's role in the system of self-regulation and to emphasize that the industry has "no authority to regulate independently of the SEC's control." ${ }^{28}$ In view of the impact which arbitration can have on investors' rights, exchange arbitration of nonmember claims outside the purview of SEC control is a wholly anomalous development that derogates significantly from any ostensibly comprehensive system of public control of self-regulation.

\section{B. Brokers' Arbitration Clauses}

Contractual clauses subjecting nonmembers to exchange arbitration appeared initially in customers' margin agreements, in which the

22. American Arbitration Association, Lawyers' Arbitration Letter No. 49, at 1 (Feb. 15, 1972).

23. 15 U.S.C. $\& 78 \mathrm{f}(\mathrm{d})$ (Supp. V 1975).

24. 15 U.S.C. $\$ 78 \mathrm{~s}$ (d) (Supp. V 1975).

25. Ware v. Merrill Lynch, Pierce, Fenner \& Smith, Inc., 414 U.S. 117 (1973).

26. Id. at 135 .

27. Pub. L. No. 94-29, 89 Stat. 97 (1975).

28. S. REP. No. 94-75, 94th Cong., 1st Sess. 23, reprinted in [1975] U.S. CODE CONG. \& AD. NEWS 179, 201. 
investor agrees to hypothecate his securities in exchange for loans from the broker for the purchase of further securities. As brokers' exposure to liability for conduct of nonmargin accounts lias expanded, however, the arbitration clause has been extended to agreements for regular cash accounts. ${ }^{28}$ The clause most widely used by major brokerage firms is one prepared by an industry group, the Association of Stock Exchange Firms:

Any controversy between you and the undersigned arising out of or relating to this contract or the breach thereof, shall be settled by arbitration, in accordance with the rules, then obtaining, of either the Arbitration Committee of the Chamber of Commerce of the State of New York, or the American Arbitration Association, or the Board of Arbitration of the New York Stock Exchange, as the undersigned may elect. ${ }^{30}$

The standard arbitration clause is clearly designed to encompass almost any dispute which might arise between an imvestor and his broker, and it has been interpreted broadly by the courts. Consistent with the principle of expansive construction of arbitration clauses in favor of their application, ${ }^{31}$ the courts liave uniformly applied brokers' arbitration clauses to disputes arising out of such peripheral transactions

29. See Hoblin, Arbitration Can Be Broker's Solution to Disputes, Sec. Reg. GuIDE (P-H) Tा 1105, in which the general counsel for a major brokerage house advises brokers to include arbitration clauses in all customer agreements "so that it is clearly understood that trades in cash accounts, and other accounts are subject to the agreement." Id. at 1148.

30. 8 C. Nichols, Cyclopedia of Legal Forms ANNotated $\$ 8.1710$, at 921 (1973). The only significant variation from this forn appearing in the agreements employed by the major brokerage houses involves the designation of the arbitration forum; occasionally, the National Association of Securities Dealers (NASD) is substituted for the American Arbitration Association as the alternative to exchange arbitration. Where the alternative to the exchange is the NASD tribunal, however, the investor wary of proindustry bias on the part of arbitrators may see his election as something of a Hobson's choice. The NASD Board of Governors appoints an Arbitration Committee with nonindustry representation "as large as [the Board] shall deem appropriate and in the public interest." This committee establishes arbitration procedures and maintains a pool of arbitrators. The only apparent limitation on its discretion in choosing arbitrators is that they come "from within and without the securities industry." NASD Code of Arbitration Procedure $\$ 8$, reprinted in NASD MANuAL $(\mathrm{CCH}) \Uparrow 3708$.

The American Arbitration Association procedure may be more palatable to investors, as the Association's pool of commercial arbitrators is utilized. The parties to the arbitration are each sent a list of arbitrators selected by an Association official for their knowledge of the securities industry and their impartiality in the dispute. Each party may strike the names of arbitrators it finds objectionable, and returns the remaining names listed in order of preference; the arbitrator with the highest mutual preference is selected. See Statement of Robert Coulson (Sept. 27, 1967), reprinted in NEw YoRK CHAMBER OF COMMERCE, supra note 10 , at 11 .

31. See Coenen v. R.W. Pressprich \& Co., 453 F.2d 1209 (2d Cir.), cert. denied, 406 U.S. 949 (1972); Lundgren v. Freeman, 307 F.2d 104 (9th Cir. 1962). 
as comnnodities trading ${ }^{32}$ and currency futures trading. ${ }^{83}$ In one particularly broad reading of such a clause, a federal district court in Robinson v. Bache \& $\mathrm{Co}^{34}$ applied an arbitration clause contained in a "Margin and Lending Agreement" to a dispute arising out of alleged unsound advice and undisclosed material adverse information. Robinson points up a difficulty with such broad interpretations. The investor who signs a margin agreement with an arbitration clause may well regard it as embracing only those disputes relating to interest rates and hypothecation problems; he is unlikely to be aware that he has subinitted all manner of unrelated disputes to arbitration as well.

Of much greater importance in the investor-broker context, however, is the extension of arbitration clauses to disputes sounding in tort, particularly securities fraud. Since the Supreme Court established that fraud in the inducement may be arbitrated pursuant to an arbitration clause in the allegedly fraudulently induced contract, ${ }^{38}$ it is clear that investors may not circumvent arbitration by alleging fraudulent misrepresentations in the making of the brokerage contract. Brokers' arbitration clauses have consistently been held applicable to claims grounded in fraud on the theory that the alleged tort liabilities "have their roots in the relationship between the parties which was created by the contract." 38

A somewhat more technical problem of interpretation concerns the beneficiaries of the arbitration clause where the investor raises claims against individual officers or employees of the brokerage firm as well as the firm itself. Since their actions in managing customers' accounts are within the course of their employment, individual defendants are generally allowed to take advantage of the arbitration clause on

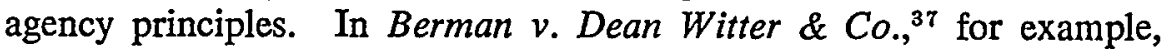
the registered representative who was alleged to have concealed certain facts was allowed to invoke the arbitration clause on the grounds that his actions im handling the account were within his agency relationship with the actual signatory, Dean Witter \& Co. A conflict arises, however, where an individual defendant connected with the broker may have some liability independent of that of the brokerage firm. In

32. See Robinson v. Bache \& Co., 227 F. Supp. 456 (S.D.N.Y. 1964); Merrill Lynch, Pierce, Fenner \& Smith, Inc. v. Griesenbeck, 28 App. Div. 2d 99, 281 N.Y.S.2d 580 (1967).

33. See Berman v. Dean Witter \& Co., 44 Cal. App. 3d 999, 119 Cal. Rptr. 130 (2d Dist. 1975).

34. 227 F. Supp. 456 (S.D.N.Y. 1964).

35. Prima Paint Corp. v. Flood \& Conklin Mfg. Co., 388 U.S. 395 (1967).

36. Berman v. Dean Witter \& Co., 44 Cal. App. 3d 999, 1003, 119 Cal. Rptr. 130, 133 (2d Dist. 1975).

37. Id. 
Stockwell v. Reynolds \& Co., ${ }^{38}$ an investor charged a broker-dealer firm and one of its partners with various elements of securities fraud arising out of the partner's alleged knowledge of certain adverse information concerning the securities issued by a corporation of which the partner was also a director. In ruling on a motion to dismiss, ${ }^{39}$ the court drew a fine distinction between two of the claims raised against the partner/ director; the claim based on rule 10b-5 was found to be subject to arbitration, apparently on agency principles, while the claim based on the partner/director's alleged breach of his fiduciary duty as a director of the corporation was not encompassed by the arbitration clause. The latter claim was found to be outside the scope of the arbitration clause since Reynolds \& Co. could in no event be liable for the director/ partner's liabilities in his capacity as a director of an outside corporation. ${ }^{40}$ Investors asserting claims against brokerage firms based on conflicts of interest ${ }^{41}$ may thus be able to avoid arbitration.

\section{II}

\section{The Arbitrability of Securities Disputes}

\section{A. The Wilko Doctrine and the Rationale of Nonarbitrability}

The longstanding practice in the securities industry of arbitrating customer claims was dealt a significant blow by the Supreme Court in Wilko v. Swan. ${ }^{42}$ The Court held that a broker's arbitration clause in a margin agreement was an invalid waiver of the investor's right to have a judicial forum hear his claims based on the Securities Act. ${ }^{43}$ The Wilko court reasoned that since section 22(a) of the Act provides for enforcement of rights created under the Act in any court of competent jurisdiction, ${ }^{44}$ an agreement to arbitrate future controversies amounted to a stipulation waiving compliance with the right to a judicial forum. The clause was thus void under the nonwaiver provision of the Securities Act, ${ }^{43}$ and the motion for a stay pending arbitration was properly

38. 252 F. Supp. 215 (S.D.N.Y. 1965).

39. A motion to dismiss can be an appropriate means of posing the existence of an arbitration clause, since a stay pending arbitration is essentially a determination that the court lacks subject matter jurisdiction over the dispute in controversy. $C f$. Macchiavelli v. Shearson, Hammill \& Co., 384 F. Supp. 21, 28 (E.D. Cal. 1974).

40. Cf. Blau v. Lehman, 368 U.S. 403 (1961) (held that outside directorship of a partner of a brokerage firm would not devolve upon the firm for purposes of section 16(b) of the Exchange Act).

41. See, e.g., Slade v. Shearson, Hammill \& Co., 517 F.2d 398 (2d Cir. 1974); Black v. Shearson, Hammill \& Co., 266 Cal. App. 2d 362, 72 Cal. Rptr. 157 (1st Dist. 1968). As in Slade, the outside directorship is often a function of an investment banking relationship.

42. 346 U.S. 427 (1953).

43. The action was brought under section 12(2) of the Securities Act, 15 U.S.C. $8771(2)(1970)$.

44. 15 U.S.C. $\$ 77 \mathrm{v}(\mathrm{a})$ (1970).

45. Securities Act \& 14, 15 U.S.C. \& 77n (1970). 
dismissed. ${ }^{48}$ The Court emphasized the congruence of its interpretation of the nonwaiver provision with effectuation of the goal of investor protection. The investor who agrees to an arbitration provision surrenders his "wider choice of courts and venue" and does so at a time when he is unable to evaluate the importance of a judicial forum. ${ }^{47}$ The Court also expressed concern that arbitration tribunals may be less familiar with the relaxed standards of fraud set forth in the Act, and noted the difficulty of securing judicial review of adverse arbitral determinations. ${ }^{48}$

The holding in Wilko has survived a substantial volume of related appellate litigation, and has been broadened where necessary to encompass analogous situations. Thus, in Reader $v$. Hirsch $\& C o .{ }^{49}$ a federal district court extended the Wilko doctrine to causes of action arising under the Exchange Act, which contains a nonwaiver provision similar to the one in the Securities Act. ${ }^{50}$ Reader further developed the Wilko doctrine by applying the principle of nonwaiver to implied causes of action arising under the securities laws; it held that the arbitration agreement could not waive the plaintiff's right of action based on violations of regulatory provisions on margin lending, despite the absence of an express civil remedy in the Act. The court set forth two principal arguments for this proposition. First, it noted that the failure of Congress to create a private cause of action in no way derogates from the court-created implied remedy. ${ }^{51}$ Second, it observed that Wilko turned on the existence of the right to a judicial forum (a right also granted in the Exchange $\mathrm{Act}^{52}$ ) rather than on the character of the right asserted. The plaintiff proceeding on an implied cause of action thus has as much right to a judicial forum as one proceeding on an express remedy.

Wilko and its progeny have generally held only that it is the waiver of the forum by the arbitration clause which is imperinissible. They clearly proceed, however, from a fear that arbitration tribunals will fail

46. The Securities and Exchange Commission participated in the suit as amicus curiae on behalf of the investor. 346 U.S. at 428 .

47. Id. at 435.

48. Id. at 436 .

49. 197 F. Supp. 111 (S.D.N.Y. 1961).

50. Exchange Act $\$ 29(\mathrm{a}), 15$ U.S.C. $\$ 78 \mathrm{cc}(\mathrm{a})$ (1970). In Scherk v. AlbertoCulver Co., 417 U.S. 506 (1974), the Supreme Court suggested some possible grounds for distinguishmg the nonwaiver sections of the two acts. Any distinction between the two nonwaiver provisions in the context of investor-broker disputes has been specifically rejected in two district court decisions, Seymour v. Bache \& Co., [1975-76 Transfer Binder] FED. SEC. L. REP. (CCH) II 95,402, at 99,057 n.2 (S.D.N.Y. 1976), and Newman v. Shearson, Hammill \& Co., 383 F. Supp. 265, 268 (W.D. Tex. 1974).

51. Cf. J.I. Case Co. v. Borak, 377 U.S. 426 (1964); Note, Implying Civil Remedies From Federal Regulatory Statutes, 77 HARv. L. REv. 285 (1963).

52. Exchange Act § 27, 15 U.S.C. \& 78aa (1970). 
to safeguard the substantive protections afforded investors by the securities laws. The Wilko Court, though it argued the importance of the forum-selection provision, failed to recognize explicitly that the arbitration clause effectively waives substantive antifraud rights. The institutional framework of securities industry arbitration, ${ }^{53}$ the vagueness of the arbitrator's duty to apply substantive law, ${ }^{54}$ and the lack of effective judicial review amount to a substantial denial of the rights and protections granted investors by the antifraud provisions. The Reader court recognized this by quoting from the Supreme Court's caveat on arbitration in Bernhardt v. Polygraphic Co. of America: ${ }^{55}$

[A]rbitration, whatever its merits or shortcomings, substantially affects the cause of action created ... . The nature of the tribunal where suits are tried is an important part of the parcel of rights behind a cause of action. The change from a court of law to an arbitration panel may make a radical difference in ultimate result. ${ }^{56}$

An investor who submits to securities industry arbitration may well be unknowingly waiving his rights to application of a lower level of scienter than is required by common law fraud, ${ }^{57}$ a relaxed requirement of proof of reliance, ${ }^{58}$ and various other presumptions and allocations of burden of proof granted the investor by the federal securities laws. These problems are exacerbated by the lack of accountability of arbitrators due to the absence of published arbitration decisions in the securities industry; ${ }^{59}$ there is virtually no criterion on which to base an evaluation of the behavior and fairness of arbitrators considering securities fraud claims.

The effect of the arbitral forum on substantive rights under the securities laws was dramatically illustrated in a case arising out of an attempt to secure judicial review of an arbitrator's award. In Sobel $v$.

53. See text accompanying notes 12-28 supra.

54. See Mentschikoff, Commercial Arbitration, 61 Colum. L. Rev. 846 (1961).

55. 350 U.S. 198 (1956).

56. Id. at 203.

57. Securities Act $\S 11,15$ U.S.C. 77k (1970). The standard for actions based on rule 10b-5 may also be lower than that required in actions based on common law fraud, although Ernst \& Ernst v. Hochfelder, 425 U.S. 185 (1976), indicates that proof of negligence is insufficient to fulfill the scienter element of that rule.

58. Affiliated Ute Citizens v. United States, 406 U.S. 128, 153-54 (1972).

59. Not only are there no published decisions; there are no decisions to publish. Securities arbitration customarily results in a one-sentence award, without reasoning or explanation. Statement of James F. Swartz (Sept. 27, 1967), reprinted in NEW YORK CHAMBER OF COMMERCE, supra note 10, at 18 . In one action attempting to force securities arbitrators to issue decisions with their awards, Sobel v. Hertz, Warner \& Co., 469 F.2d 1211 (2d Cir. 1972), the New York Stock Exchange filed an amicus brief suggesting that a requirement of written decisions would put an end to securities industry arbitration of customer claims. Id. at 1215 n.7. See text accompanying notes 168-69 infra. 
Hertz, Warner \& Co., ${ }^{80}$ an investor had charged the brokerage house and two of its registered representatives with inarket manipulation, unauthorized trading, and fraudulent misrepresentations in connection with activity in his accounts. The registered representatives were subsequently indicted. ${ }^{.1}$ The investor elected to arbitrate his claims, and signed a submission agreement to that effect. The claim went to exchange arbitration, where it was denied in an award without decision or reasoning. After the arbitration, the registered representatives were convicted of conspiracy and market manipulation. The litigation in Sobel involved an atteinpt to overturn the award on grounds that it violated public policy and was rendered "in manifest disregard" of the securities laws; although the investor prevailed in the district court, the Second Circuit reversed. ${ }^{62}$

The composition of securities arbitration tribunals, the relative positions of investors and brokers on the desirability of arbitration, and the curious result in the Sobel case, all indicate that investors are likely to get short shrift on their securities fraud claims submitted to arbitration. ${ }^{63}$ Since the members of these arbitration tribunals are frequently the targets of the antifraud provisions they are asked to interpret, it is not surprising that they apply a narrow reading of the federal scheme of regulation. To the extent that the Wilko doctrine has prevented arbitration of investors' securities fraud claims, it has proven to be an essential extension of the nonwaiver provisions and a vital means of preserving the public character of securities regulation.

The emphasis on judicial rather than arbitral disposition of claims arising under the federal securities laws is consistent with iudicial treatment of other areas in which private enforcement is affected with a public interest. ${ }^{64}$ The most notable example is the private enforce-

60. 469 F.2d 1211 (2d Cir. 1972). Sobel is discussed extensively in E. BrodskY, Guide to SeCuRITIES LITIGATION 293-312 (1974).

61. See United States v. Projansky, 44 F.R.D. 550 (S.D.N.Y. 1968).

62. Sobel v. Hertz, Warner \& Co., 469 F.2d 1211 (2d Cir. 1972), rev'g 338 F. Supp. 287 (S.D.N.Y. 1971).

63. The SEC compiled the following statistics on the disposition of arbitration claims by the New York Stock Exchange for the period 1957-61. It should be noted that these statistics include disputes between exchange members in addition to investor claims:

Inactive for failure to proceed ...___ 129

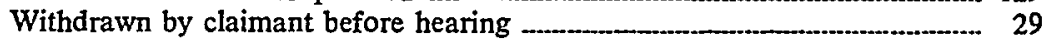

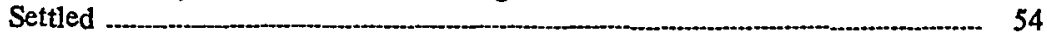

Award:

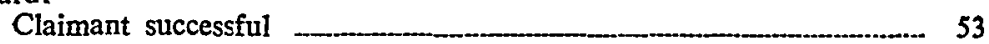

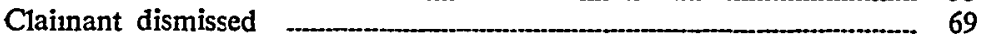

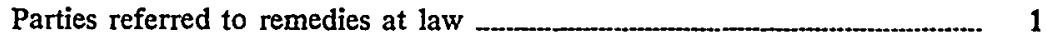

Jurisdiction declined

SEC SPECIAL STUdY, supra note 10, ch. 12, at 559.

64. See Beckman Instruments, Inc. v. Technical Dev. Corp., 433 F.2d 255 (8th Cir. 1970), cert. denied, 401 U.S. 976 (1971). 
ment of the antitrust laws; a franchisee who submits to an arbitration clause in a franchise agreement cannot be forced to arbitrate his claims arising under the federal antitrust statutes, even in the absence of any statutory nonwaiver provision. ${ }^{65}$ In American Safety Equipment Corp. v. J.P. Maguire \& $C_{0 .}{ }^{66}$ the Second Circuit held that "a clann under the antitrust laws is not merely a private matter," ${ }^{67}$ and is thus inappropriate for hearing by a private tribunal. Securities regulation relies heavily on private attorneys general $;^{68}$ the Wilko doctrine reflects an effort to preserve the private enforcement of the securities laws. Permitting brokers to force clainns under the securities laws into arbitration would frustrate the judicial purpose in implying civil causes of action froin regulatory provisions. The charges would disappear into the closed arbitration process, stifling the development of the law and inhibiting public scrutiny of the industry practices brought into question. Even assuming that it is the arbitrator's duty to apply substantive law, his duty to further a court-fashioned regulatory scheme is unclear; in any event, there is no realistic method of evaluating whether the public character of private enforcement is given proper consideration. Judicial rather than private hearing of securities fraud claims is a sine qua non for any plan to supervise and regulate the industry through the use of private civil actions.

There are, of course, other valuable rights surrendered in arbitration-rights which are subsumed in the right to a judicial forum. Most crucial to investors engaged in antifraud actions against securities brokerage firms is the right to a jury trial in the federal courts. ${ }^{69}$ Also important in the investor-broker context is the surrender of discovery rights; although the parties to an arbitration proceeding generally have a right of subpoena, ${ }^{70}$ other forms of prehearing discovery are often unavailable or strictly limited. The lack of discovery rights can be a serious obstacle to the prosecution of the investor's case; without discovery, he may be unable to learn the volume of commissions generated by his account in relation to other accounts, the nature of recommendations made by the broker's research department, and possible conflicts of interest. The broker generally has more information to utilize in preparing his defense, including forms completed by the investor, confirmation slips, and account statements. Although ex-

65. Cobb v. Lewis, 488 F.2d 41 (5th Cir. 1974); Power Replacements, Inc. v. Air Preheater Co., 426 F.2d 980 (9th Cir. 1970).

66. 391 F.2d 821 (2d Cir. 1968).

67. Id. at 826.

68. Cf. J.I. Case Co. v. Borak, 377 U.S. 426 (1964).

69. U.S. CoNST. amend. VII.

70. E.g., 9 U.S.C. $\$ 7$ (1970); CAL. CODE CIV. Pro. $\$ 1282.6$ (West 1972); N.Y. Crv. PRAC. LAW $§ 7505$ (McKinney 1963). 
change arbitration procedure generally allows a party to move for a postponement if he is "surprised" at the hearing, ${ }^{71}$ this option is not very meaningful to the investor with only vague bases for his claims and without access to further information with which to refine and substantiate those claims.

\section{B. The Applicability of Wilko to Investor Causes of Action}

The expandimg scope of liability imposed on brokers for violations of various statutory, administrative, and self-regulatory prohibitions ${ }^{72}$ makes uncertain the determination of what constitutes a liability arising under the federal securities laws. When Wilko was decided, only express civil remedies were at stake, simce the theory of implied civil liability from federal regulatory provisions was still im an embryonic state. The extension of Wilko to implied rights of action in Reader provided a fairly clearcut construction of the scope of Wilko nonarbitrability, since such implied rights are generally tied to an identifiable provision in the securities acts. More troublesome, however, is whether liabilities for the violation of exchange rules, ${ }^{73}$ NASD rules, ${ }^{74}$ and Federal Reserve Board margin lending requirements ${ }^{75}$ are habilities created by the securities laws such that they are subject to the nonwaiver provisions and the Wilko doctrine. To the extent that these self-regulatory mechanisms substitute for statutory and admimistrative regulation, they should be considered equivalent to securities laws for purposes of determining the arbitrability of claims arising under them. The extent to which the self-regulatory rules of the industry are mere substitutes for SEC regulation is evident from an analysis of SEC rules applicable to nonmember broker-dealers, as they substantially parallel exchange and NASD rules. ${ }^{76}$ The Commission's promulgation of rules for nonmember broker-dealers analogous to those adopted by industry institutions pursuant to self-regulatory schemes evidences an imtent to inte-

71. See, e.g., New York Stock Exchange Arbitration Rule 485, reprinted in 2 NYSE GUIDE (CCH) II 2485.

72. See, Jacobs, The Impact of Securities Exchange Act Rule $10 b-5$ on BrokerDealers, 57 CORNELL L. REV. 869 (1972).

73. See, e.g., Buttrey v. Merrill Lynch, Pierce, Fenner \& Smith, Inc., 410 F.2d 135 (7th Cir.), cert. denied, 396 U.S. 838 (1969). See also Lowenfels, Implied Liabilities Based Upon Stock Exchange Rules, 66 Colum. L. Rev. 12 (1966).

74. See Avern Trust v. Clarke, 415 F.2d 1238 (7th Cir. 1969), cert. denied, 397 U.S. 963 (1970).

75. Pearlstein v. Scudder \& German, 429 F.2d 1136 (2d Cir. 1970), cert. denied, 401 U.S. 1013 (1971). But see Gordon v. duPont Glore Forgan, Inc., 487 F.2d 1260 (5th Cir. 1973), cert. denied, 417 U.S. 946 (1974).

76. See, e.g., Exchange Act Rule 15b10-3, 17 C.F.R. 240.15b10-3 (1976), substantially a codification of the industry's "know your customer" rule. See note 90 infra. 
grate such schemes of broker-dealer regulation with the more general provisions of the securities laws.

The public character of the system of exchange self-regulation is indicated by the three sections of the Exchange Act that regulate registration of securities exchanges and national securities associations. Section 6(b) requires exchanges, as a condition of registration, to promulgate rules promoting "just and equitable principles of trade" and providing for discipline of members engaging in "fraudulent and manipulative acts and practices." ${ }^{7}$ Section $15 \mathrm{~A}(\mathrm{~b})(8)$ is a similar provision relating to national securities associations, with an additional requirement that such groups prevent discriminatory commission practices. $^{78}$ Section $28(\mathrm{~b})$ exempts the internal arbitration procedure of "any self-regulatory organization" from the nonwaiver provisions insofar as they affect members. ${ }^{70}$ In addition, the Exchange Act provides that the SEC may request modification of rules of self-regulatory organizations, or may promulgate superseding regulations. ${ }^{80}$

In what is perhaps the leading case on implication of private rights of action from the rules of self-regulatory organizations, Colonial Realty Corp. v. Bache \& Co. ${ }^{81}$ the Second Circuit took a back-door approach to the issue of arbitrability of claims based on violation of exchange rules. In discussing the availability of a private right of action, it posed the prospective nonarbitrability of these claims under the Wilko doctrine as a reason for denying the right of action:

The consequences of the view urged by Colonial would be so disruptive as to require much more impressive evidence of congressional purpose than we can discern. For example, as illustrated by this very case, the widely adopted practice of resorting to arbitration as a means of settling controversies between stockbrokers and their customers would be outlawed whenever the customer chose to rely not on breaches of contract or negligence simpliciter but on the nore sophisticated theory that the broker's acts were inconsistent with just and equitable principles of trade' $\ldots . .^{82}$

Colonial declines to recognize a right of action on the grounds that such recognition would render the underlying claims nonarbitrable. This curious reasoning is inconsistent with the more conventional criteria set forth earlier in the opimion for determining whether a private cause of action exists. ${ }^{83}$ The court sought to avoid a result that

77. 15 U.S.C. $\& 78 f(b)(5)$ (Supp. V 1975).

78. 15 U.S.C. \& 780-3(b)(6) (Supp. V 1975).

79. 15 U.S.C. $\& 78 \mathrm{bb}(\mathrm{b})$ (Supp. V 1975).

80. Exchange Act $\$ 19,15$ U.S.C. $\$ 78$ s (Supp. V 1975).

81. 358 F.2d 178 (2d Cir.), cert. denied, 385 U.S. 817 (1966).

82. Id. at 182 .

83. Id. at 181-82. 
would "saddle the federal courts with garden-variety customer-broker suits", 84 it viewed implication of a private right of action as undesirable because it would arm the investor witl a nonarbitrable claim under Wilko, and would convert the dispute into an Exchange Act suit under the exclusive jurisdiction of the federal courts. ${ }^{85}$ The court's reasoning seems misguided. The availability of an implied right of action should not depend on the existence of a private method of dispute resolution. The Supreme Court has set forth criteria for determining whether a cause of action exists for violation of a regulatory provision; ${ }^{80}$ the effect of the prospective cause of action on the arbitrability of underlying common law causes of action is not a recognized criterion. If Congress intended to generate a self-regulatory scheme in the securities markets institutions for the protection of investors, and included this scheme within the framework of the Exchange Act, that Act's forum clause should apply to claims properly based on industry regulatory provisions.

In Starkman v. Seroussi, ${ }^{87}$ a federal district court purported to apply the Colonial Realty criteria for implying private rights of action for violations of exchange rules, but reached a different result by ignoring the arbitrability issue. The investor alleged, inter alia, violations by the broker of rules $345.17,,^{88} 345.19,{ }^{80}$ and $405^{90}$ of the New York Stock Exchange. The Court held that a private cause of action should be implied under these rules simce they were specifically drawn regulatory provisions designed to protect investors, in contrast to the catchall rule at issue in Colonial Realty. Significantly, the court did not consider the effect of its ruling on the arbitrability of the claims in deternnining whether a cause of action existed. It separated these issues, concluding first that the cause of action existed and then proceeding to the issue of arbitrability of the implied right of action.

In considering the arbitrability issue, the court in Starkman was required to deternnine whether the implied liability arose froin a "duty created by [the Exchange Act]" and was thus subject to the nonwaiver provision. $^{91}$ The court recognized that exchange rules are an integral

84. Id. at 183.

85. See Comment, Federal Jurisdiction Over Private Sults Alleging Violations of Stock Exchange Rules, 17 B.C. IND. \& CoM. L. REv. 443 (1976).

86. See J.I. Case Co. v. Borak, 377 U.S. 426 (1964).

87. 377 F. Supp. 518 (S.D.N.Y. 1974).

88. Rule 345.17 prohibits brokers from making guarantees against losses and from entering into agreements to share profits from customers' accounts. 2 NYSE Guide (CCH) ๆ 2345.17.

89. Rule 345.19 requires member firms to investigate the background of any prospective employes. 2 NYSE Guide (CCH) I 2345.19.

90. Rule 405 is the "know your customer" rule by which member firms are required to exercise due diligence to learn "the essential facts" about customers' proposed accounts and transactions. 2 NYSE GUIDE (CCH) II 2405.

91. Exchange Act $\$ 29(\mathrm{a}), 15$ U.S.C. $\$ 78 \mathrm{cc}(\mathrm{a})(1970)$, 
part of securities regulation, and concluded that the claims based upon them were sufficiently related to Exchange Act sections 6 and $19^{92}$ to invoke the nonwaiver provision and thus stay the arbitration proceeding. ${ }^{23}$ The result in Starkman certainly does not follow from that in Colonial Realty, which had sought to shield the federal courts from "garden-variety" customer-broker suits; suits based on specific exchange rules are as much "garden-variety" as those based on catchall provisions. By distinguishing the implication of a right of action from the arbitrability of that right of action, Starkman illustrates the flaw in Colonial Realty and establishes the applicability of the nonwaiver provision to claims arising under the rules of self-regulatory organizations.

The arbitrability determination under the Wilko doctrine is more complicated where an investor charges his broker with violating regulations concerning extension of credit for purchases of securities on margin. The framework for regulation of margin transactions begins with section 7 of the Exchange Act, which authorizes the Federal Reserve Board to promulgate rules and regulations "for the purpose of preventing excessive use of credit for the purchase or carrying of securities"; ${ }^{94}$ subsection (7)(c) makes it unlawful for any broker to extend credit in violation of Federal Reserve Board rules. The rule applicable to broker-dealers is Regulation $T{ }^{95}$ which sets minimum collateral requirements, specifies time periods for deposits into margin accounts, and requires brokers to liquidate certain undermargined accounts. The courts have generally upheld the existence of a private civil remedy for violations of Regulation $\mathrm{T}$ requirements, ${ }^{96}$ although the subject is still a matter of some contention. ${ }^{97}$

Whether a liability under Regulation $\mathrm{T}$ arises from a duty created by the Act is, however, another question. This situation might seem to parallel the analysis of exchange rule violations and to constitute another instance in which Congress has delegated to a body other than the SEC the formulation of specific rules within the framework of the securities laws. Despite the apparent structural symmetry between Regulation $\mathrm{T}$ violations and violations of exchange rules, the courts are in conflict over the applicability of the Wilko doctrine to claims based

92. See text accompanying notes 77-80 supra.

93. 377 F. Supp. at 524 .

94. 15 U.S.C. $\$ 78 \mathrm{~g}(1970)$.

95. 12 C.F.R. \$ 220 (1976).

96. See Note, Federal Margin Requirements as a Basis for Civil Liability, 66 COLUM. L. Rev. 1462 (1966).

97. See, e.g., Gammage v. Roberts, Scott \& Co., [1974 Transfer Binder] FED. SEC. L. REP. (CCH) I 94,760 (S.D. Cal. 1974) (citing the legislative history of the margin provisions aud questioning the deterrent effect of implying a private right of action). 
on the margin requirements; this conflict appears to be one borne of confusion rather than substantial disagreement.

The issue first appeared in Reader where the court seemed to assume that the violations of section 7 alleged in the complaint arose out of the Exchange Act and were thus nonarbitrable. The court failed to note that section 7 is primarily an enabling provision for the substantive requirements found in Regulation T. Although the section makes it unlawful for brokers to violate the applicable provisions of the Federal Reserve Board regulations, it is properly the regulations themselves that are violated and not the enabling provision. In Robinson v. Bache \& Co., ${ }^{98}$ a federal district court relied on Reader in finding that an action alleging violation of Regulation $T$ was arbitrable because it did not appear from the factual elements of the complaint that a violation had occurred. In a passage which has been widely misunderstood as holding that Regulation $\mathrm{T}$ violations are arbitrable, ${ }^{99}$ the court said,

Since it appears that defendant inaintained a separate coinınodity account for plaintiff pursuant to Regulation $T$ issued by the Board of Governors of the Federal Reserve System pursuant to the Securities Exchange Act of 1934 (12 C.F.R. $\S \S 220.1-220.8$ ), the existence of Regulation $T$ does not preclude arbitration. ${ }^{100}$

The court in Robinson inade a factual determination; since there was no actual commingling of funds in the different accounts, Regulation $\mathrm{T}$ was not violated, and the dispute was therefore subject to arbitration. The logical converse of this, of course, is that if there had been a Regulation $T$ violation, arbitration would have been precluded by the Wilko doctrine. The court's reliance on Reader ${ }^{191}$ supports this interpretation of the Robinson language.

The ambiguous language in Robinson, however, has led at least one court to conclude exactly the opposite. In Macchiavelli $v$. Shearson, Hammill \& Co., ${ }^{102}$ a federal district court, citing Robinson, expressly held that claims based on Regulation $T$ violations are arbitrable. The court stayed the legal proceedings based on alleged Regulation $\mathrm{T}$ violations and granted a motion to compel arbitration. The court failed to support this holding with any reasoning; it merely cited Robinson, leading one to believe that it inisread that case.

Subsequent cases dealing with this issue have proceeded on the assumption that claims based on Regulation $\mathrm{T}$ are nonarbitrable without

98. 227 F. Supp. 456 (S.D.N.Y. 1964).

99. See, e.g., 6 L. Loss, Securmies Regulation 3933 (2d ed. Supp. 1969).

100. 227 F. Supp. at 458.

101. Id.

102. 384 F. Supp. 21 (E.D. Cal. 1974). 
directly confronting the problem. ${ }^{103}$ Since only the allegations of the complaint are considered in determining the issue of arbitrability, ${ }^{104}$ the mere recitation of section 7 of the Act in conjunction with a cause of action based on Regulation $T$ may prevent the issue from ever arising.

There is little reason to differentiate between rights created by stock exchange rules and rights created by Regulation $T$, as both are clearly within the matrix of the regulation of secondary trading envisioned in the Exchange Act. That Congress chose to allow the Federal Reserve Board to set specific margin requirements reflects a determmation that that body's expertise and control over imterest rates in the economy as a whole will assure that broker-dealer lending patterns will not fall out of step with interest rates in other sectors of the economy. It is difficult to perceive any intent to remove the requirements for margin trading from the jurisdiction of the SEC and, more importantly, the exclusive jurisdiction of the federal courts. Given the source of the authority for Regulation $T$, it seems evident that liabilities for claims based upon its substantive requirements are properly construed as having been created by the Exchange Act, and should thus be accorded the nonwaivable right to be heard in a judicial forum.

\section{The Arbitrability of Existing Disputes}

The Wilko holding was clearly limited to agreements to arbitrate future controversies, leaving unresolved the issue of whether an investor and broker can agree to arbitrate a dispute after it has arisen. ${ }^{105}$ In Wilko, the SEC asserted a distinction between future and existing controversies in its amicus brief, ${ }^{108}$ and Justice Jackson supported this distinction in his concurring opinion. ${ }^{107}$

There are persuasive reasons for excepting agreements to arbitrate existing controversies froin the Wilko doctrine. First, an investor who submits to arbitration after he becomes aware of his claim is more likely to investigate the desirability of having his claim heard by an arbitration tribunal. Second, the arbitration submission is analogous to a settleinent agreeinent, which may operate to bar further action. ${ }^{108}$ Third, arbitration should be available to investors with small claims which do not exceed the threshold cost of securities litiga-

103. See, e.g., Kavit v. A.I. Stamm \& Co., 491 F.2d 1176 (2d Cir. 1974); Berens v. Bache \& Co., [1973-74 Transfer Binder] Fed. Sec. L. Rep. (CCH) I 94,387 (S.D. N.Y. 1974); Tilly Foster Real Estate Corp. v. Shearson, Hammill \& Co., [1973 Transfer Binder] FED. SEC. L. REP. (CCH) \ 94,073 (S.D.N.Y. 1973).

104. See text accompanying note 128 infra.

105. 346 U.S. at 435.

106. See 3 L. Loss, Securities Regulation 1814 (2d ed. 1961).

107. 346 U.S. at 438 (Jackson, J., concurring).

108. See Callen v. Pennsylvania R.R., 332 U.S. 625 (1948). 
tion. Finally, the purpose of the nonwaiver provisions and the Wilko doctrine is to allow investors to make an intelligent choice of forums, and not wholly to foreclose voluntary arbitration. ${ }^{109}$

In separate lawsuits asserting essentially the same claim, both the Third Circuit and the Pennsylvania Supreme Court determined that an agreement to arbitrate an existing dispute does not violate the nonwaiver provisions of the federal securities laws. An investor complaining of unauthorized transactions in her margin accounts voluntarily submitted a claim to exchange arbitration after being advised by both the SEC and the New York Stock Exchange that she could pursue her claim either in arbitration or in the courts. After the arbitrators awarded her only a small portion of her claim, she commenced an action to overturn the award on various grounds, including the nonwaiver provisions. The Pennsylvania Supreme Court rejected her claim in Moran v. Paine, Webber, Jackson \& Curtis, ${ }^{110}$ as did the Third Circuit; ${ }^{111}$ both courts read Wilko and Reader as distinguishing between future and existing controversies, and held that the argunnents for voiding an agreenent to arbitrate future controversies are "generally inapplicable" to an agreement to arbitrate an existing controversy. ${ }^{112}$

What constitutes an existing controversy may be difficult to determine. Typically, as in Moran, ${ }^{113}$ the arbitration subinission follows a complaint by the investor and soine attempt to settle the dispute, so that the issues are well-defined by the tine of the submission, and the existing controversy can be easily identified. Where the arbitration agreement is completed sometime after the investor-broker relationship has commenced, however, or where there is some question as to the investor's awareness of the nature of his claims, the applicability of the Moran rule is questionable. In Seymour v. Bache \& Co., ${ }^{114}$ the investor entered into a inargin agreement with the defendant broker that contained an arbitration clause. Three years later he signed another margin agreement, with an identical arbitration clause. When the investor brought suit for churning ${ }^{115}$ of his account, the broker moved for a stay

109. See generally Note, Enforceability of Arbitration Agreements in Fraud Actions Under the Securities Act, 62 YALE L.J. 985, 994-95 (1953).

110. $422 \mathrm{~Pa} .66,70,71,220$ A.2d 624, 626-27 (1966).

111. Moran v. Paine, Webber, Jackson \& Curtis, 389 F.2d 242, 245-46 (3d Cir. 1968).

112. $389 \mathrm{~F} .2 \mathrm{~d}$ at $246 ; 422 \mathrm{~Pa}$. at $70-71,220 \mathrm{~A} .2 \mathrm{~d}$ at 627.

113. See text accompanying notes 110-12 supra.

114. [1975-76 Transfer Binder] Fed. Sec. L. REP. (CCH) đ 95,402 (S.D.N.Y.), aff'd mem., 538 F.2d 313 (2d Cir. 1976), cert. denied, 45 U.S.L.W. 3275 (U.S. Oct. 12, 1976).

115. "Churning" is excessive trading by a broker in an account in which he holds discretionary or quasi-discretionary powers, for the purpose of generating commissions. See Note, Churning by Securities Dealers, 80 HARv. L. REv. 869 (1967). 
pending arbitration, arguing that much of the activity alleged in the complaint occurred before the execution of the second agreenent, rendering the dispute an existing one under Moran and thus outside the reach of the Wilko doctrime. A federal district court denied the broker's motion, finding that the reasons supporting the arbitrability of existing disputes did not apply. The court emphasized that there must be a "voluntary and intelligent waiver" of the right to a judicial forum before an existing dispute could be found to be beyond the reach of the Wilko doctrine. ${ }^{110}$

Whether a dispute is existing at the time of the agreeinent to arbitrate is irrelevant where both parties are exchange meinbers. ${ }^{117}$ A surprising volume of litigation involves an investor who has become a partner or major shareholder in a brokerage firm as a result of a period of investing solely as a customer, and who brings suit for the conduct of his account during the period prior to his acquiring an interest in the firn. As a partner or a director of a member firm, he is usually required to become an allied member of the exchange, which subjects hin to the internal arbitration procedure. The requireinent that all controversies between exchange members be submitted to arbitration has been held to apply to claims arising before membership as well as later claims, ${ }^{118}$ however, since the offer of membership in the firm often seems to be directed towards forcing the investor's claims into arbitration, ${ }^{119}$ the courts have fashioned certain exceptions to this rule.

116. [1975-76 Transfer Binder] Fed. SEC. L. REP. (CCH) at 99,052. Not only must the investor be aware that a dispute exists, he must have some knowledge that it is a securities dispute. In Fischer v. New York Stock Exch., 4.8 F. Supp. 745 (S.D.N.Y. 1976), subordinated lenders of a defunct brokerage house sued the New York Stock Exchange for alleged complicity in the brokerage firm's failure to disclose its financial condition. When the brokerage firm went into liquidation, the lenders signed a custodial agreement providing that any disputes arising out of the disposition of the assets of the firm would be subject to arbitration. Although the arbitration agreement was clearly executed after the lenders became aware of their disagreement over the firm's ability to meet its obligations, the court refused to stay the action on the grounds that the plaintiffs were unaware that it was a securities controversy at the time the agreement was executed, such awareness being "crucial to a determination of when the controversy arose." Id. at 750 .

117. Exchange Act $\$ 28(b), 15$ U.S.C. $\$ 78 b b(b)$ (Supp. V 1975). See text accompanying note 15 supra.

118. Coenen v. R.W. Pressprich \& Co., 453 F.2d 1209 (2d Cir.), cert. denied, 406 U.S. 949 (1972).

119. E.g., Danford v. Swabacher, 342 F. Supp. 65 (N.D. Cal. 1972), appeal dismissed, 488 F.2d 454 (9th Cir. 1973). In Danford, the investor alleged that the plan by which he became subject to the exchange rules was an integral part of the defendant's scheme to defraud him by bringing his account under the partnership's control. The court stated:

A security dealer may not defraud a customer, in the course of the fraud convert him into an Exchange member, and thereby deprive him of the protection of the securities laws and the courts.

342 F. Supp. at 69. 
Where the dispute arises out of transactions by the member in his capacity as an investor, there is a marked reluctance to force the meinber into arbitration. In Laupheimer v. McDonnell \& Co., ${ }^{120}$ a registered representative who was offered stock in his employer's firm, the purchase of which required him to become an officer and nnember of the New York Stock Exchange, later brought suit on charges that the firm had misrepresented its financial condition. The Second Circuit refused to entertain the brokerage firm's motion for a stay pending arbitration, fimding that the alleged fraud was perpetrated against the plaimtiff "not as an officer of the firm, but as an outsider."121 A sinilar result was reached in another case arising out of the same stock offering, partially on the theory that the stock purchaser's exchange membership arose out of his position as house counsel rather than any position dealing directly with brokerage services. ${ }^{122}$

Intra-Exchange arbitration is exempted froin the nonwaiver provisions for two reasons: (1) to permit the exchange to fulfill its disciplinary and dispute-resolving function ${ }^{123}$ in an efficient manner, without prejudice to the imvestimg public; ${ }^{124}$ and (2) because exchange members are presumably sophisticated enough to protect their own interests in arbitration, and thus need no protection from waiver. Where a broker traps un unwary investor into arbitration by combining a fraudulent sale of securities with meinbership in the exchange, these reasons supporting the arbitrability of intra-exchange disputes do not apply. This conclusion is reinforced by the fact that applications for exchange meinbership (and agreements to abide by the constitution and rules of the exchange) do not explicitly refer to arbitration. ${ }^{125}$

The efforts by soine brokers to circuinvent Wilko by subjecting customers to intra-exchange arbitration cannot be justified by Moran. Moran, by its language, is limited to wilful, knowing submission of matured claims to arbitration. The exemption of intra-exchange arbitration from the nonwaiver provisions is expressly limited to "actions taken by the authorities of such self-regulatory organization to settle disputes between its inembers and participants." ${ }^{128}$ This express

120. 500 F.2d 21 (2d Cir. 1974).

121. Id. at 25 .

122. Rice v. McDonnell \& Co., [1974 Transfer Binder] Fed. SEc. L. ReP. (CCH) If 94,932 (S.D.N.Y. 1974).

123. See Ayres v. Merrill Lynch, Pierce, Fenner \& Smith, Inc., 538 F.2d 532 (3d Cir. 1976).

124. See Axelrod \& Co. v. Kordich, Victor \& Neufeld, 451 F.2d 838 (2d Cir. 1971).

125. See Newman v. Shearson, Hammill \& Co., 383 F. Supp. 265, 269 (W.D. Tex. 1974).

126. 15 U.S.C. $\S 78 \mathrm{bb}(\mathrm{b})$ (Supp. V 1975). The section also embraces "any person who has agreed to be bound" by exchange rules. 
limitation evidences no imtent to countenance the sort of schemes devised by the defendants in Laupheimer and similar cases. ${ }^{127}$ In view of the limits to the self-regulatory exemption, the exchanges might well be more circumspect in evaluating inembership applications and hearing claims of investors coerced into arbitration by virtue of their exchange membership.

\section{III}

\section{Litigation of the ARbitrability Issue}

\section{A. Procedural Considerations}

The procedural context in which the issue of arbitrability arises can be critical to its ultimate determination. Courts usually determine the issue at the pleading stage, relying on the complaint to determine whether the causes of action presented are subject to arbitration. ${ }^{128}$ The inere presence of related nonarbitrable claims, no matter how groundless, can often prevent referral to arbitration of otherwise arbitrable claims; in the interest of judicial econoiny, courts are reluctant to permit such claims to be separated and tried in different forums. ${ }^{129}$

The battle over arbitrability typically follows this pattern: the investor coinplains to his broker, who may or may not offer to arbitrate; the investor files suit; the broker moves for stay of the action pending arbitration pursuant to the Federal Arbitration Act ${ }^{130}$ or a state arbitration statute. ${ }^{131}$ Where the broker has a substantial counterclaim, or seeks quick resolution of the dispute, he may inove to compel specific performance of the agreement to arbitrate. ${ }^{132}$

That the motion to stay the proceedings or to compel arbitration is generally heard before any substantive consideration of the plaintiff's claims is a major tactical advantage for investors seeking to avoid arbitration. By framing a complaint principally in terms of federal securities laws violations, the plaintiff can often avoid arbitration of any of

127. See note 119 supra.

128. See Maheu v. Reynolds \& Co., 282 F. Supp. 423 (S.D.N.Y. 1967).

129. See text accompanying notes 149-54 infra.

130. 9 U.S.C. $\$ 3(1970)$.

131. The importance of state arbitration statutes in these disputes is considerably diminished as a result of the Supreme Court's determination in Prima Paint Corp. v. Flood \& Conklin Mfg. Co., 388 U.S. 395 (1967), that defendants faced with federal claims have access to the Federal Arbitration Act to enforce an arbitration agreement covering those claims.

132. See 9 U.S.C. $\$ 4$ (1970). A defendant might conceivably attempt to halt the legal proceedings by a motion under FED. R. Crv. P. 12(b)(1), since the assertion of a valid arbitration clause is an attack on the court's subject matter jurisdiction. See Macchiavelli v. Shearson, Hammill \& Co., 384 F. Supp. 21 (E.D. Cal. 1974). 
his claims, even if the securities laws claims are dismissed soon thereafter. This tactic was apparently followed by the investor in Kavit $v$. A.L. Stamm \& Co., ${ }^{133}$ who sued his broker for losses in his account relating to the Texas Gulf Sulphur affair. The complaint alleged various securities laws violations, as well as common law negligence and conversion. The broker's motion for a stay pending arbitration on all claims was denied under Wilko because of the existence of at least some federal securities laws claims. The broker failed to appeal this ruling; ${ }^{134}$ at trial, the federal claims were dismissed, but the court found for the plaintiff on the common law claims. These common law claims would no doubt have been arbitrated rather than litigated had the federal claims not been appended at the time of the arbitrability determination. Judge Friendly sharply criticized this use of the court's pendent jurisdiction:

[T] he state claims would have gone to arbitration under the standard customer agreement if they had stood alone. Permitting a plaintiff to try such claims on the basis of pendent jurisdiction not only adds to the burdens of the federal courts and deprives the parties of the opportunity to obtain in a more fitting tribunal "a surer-footed reading of applicable law". . . but it strips the defendant of its contractual right to arbitration." 135

Often the broker poses the existence of the arbitration agreement as an affirmative defense rather than moving for a stay or an order compelling arbitration. An investor faced with such a defense in Starkman v. Seroussi ${ }^{136}$ responded by moving for a stay of the threatened arbitration, arguing that Wilko precluded arbitration of his Exchange Act claims; the stay of arbitration was granted. Starkman indicates that the investor can take the offensive and force a determination on the issue of arbitrability before the defendant can attempt to ferret out the insubstantial federal claims by discovery and pretrial motions.

Disputes arising out of a broker's sale of its customer's hypothecated securities pursuant to inargin maimtenance calls ${ }^{137}$ often involve clains by both parties. Where the value of margined securities quickly declines, the broker may be left with insufficient security to cover its loans to the investor, and may seek to recover the balance. The investor whose account has been liquidated often presses various claims

133. 491 F.2d 1176 (2d Cir. 1974).

134. The Second Circuit stated that the original denial of the stay was appealable and would have been reversed had it been appealed. Id. at 1181-82.

135. Id. at 1178-79.

136. 377 F. Supp. 518 (S.D.N.Y. 1974).

137. A "margin maintenance call" is a notification by a broker that he intends to sell the customer's hypothecated securities to bring the levcl of cquity in the margin account up to the required percentage. 
against the broker, ranging from allegations of margin regulation violations to charges of misrepresentations concerning the securities purchased on margin. Although the broker may assert a right to arbitrate its claims for the unpaid balance of margin loans, the investor's defense or counterclaim is likely to be based on one or more provisions of the securities laws, and nnay cast the entire dispute into the realm of Wilko nonarbitrability.

In a pair of representative cases, Berens $v$. Bache \& Co., ${ }^{138}$ and Tilly Foster Real Estate Corp. v. Shearson, Hammill \& Co., ${ }^{139}$ a federal district court held that a customer's defense or counterclaim alleging securities laws violations was sufficient to prevent arbitration of a broker's claim against the investor for postliquidation margin indebtedness. In Berens, the broker insisted on arbitration of its own claims, even if the investor's fraud claims were to be heard in court; the broker promised that it would not raise the fraud claims in the anticipated arbitration. The court rejected this argument and enjoined any further arbitration proceedings, noting that the fraud clain was not the broker's to raise in any event. The court concluded that the broker would have no clains against the investor but for the acts alleged by the investor. ${ }^{140}$

Tilly Foster may have presented a more compelling situation for a stay of arbitration, since there was substantial symmetry between the broker's claim against the investor and the investor's defenses based on the securities laws. The broker in Tilly Foster initiated arbitration proceedings to recover money it had lost on "buy-ins" in connection with the transfer of a nonpurpose loan account from another brokerage firm. ${ }^{141}$ The investor responded by filing an action for declaratory judgment that its defenses rendered the dispute nonarbitrable. The investor's defenses were directly related to the broker's clain; they alleged violations of minimum equity rules and the "know your customer" rules of the New York Stock Exchange ${ }^{142}$ in the execution of the original loan commitment, as well as violations of Regulation $\mathrm{T}$ on time limits for the buy-ins.

The cases involving brokers' clains for postliquidation debts arising from margin accounts are disturbing in that they permit imvestors to avoid arbitration of arbitrable issues merely by interposing defenses that recite securities laws violations. Arbitration, although mappropri-

138. [1973-74 Transfer Binder] Fed. Sec. L. Rep. (CCH) đ 94,387 (S.D.N.Y. 1974).

139. [1973 Transfer Binder] Fed. SEC. L. ReP. (CCH) đ 94,073 (S.D.N.Y. 1973),

140. [1973-74 Transfer Binder] FED. SEc. L. REP. (CCH) at 95,337.

141. "Buy-ins" are purchases by a broker to cover customer sales in a margin account; a "nonpurpose loan" is a loan made by a brokerage house for purposes other than the purchasing or carrying of registered securities.

142. See note 90 supra. 
ate for securities fraud claims, may be proper for the disposition of simple debt claims arising out of brokerage transactions. Brokers have a substantial interest in arbitrating such claims, since the sums involved are usually too insignificant to justify mcurring the threshold costs of litigation. The benefits of speed, efficiency, and economy usually attributed to arbitration ${ }^{143}$ can be realized without jeopardizing judicial enforcenent of the federal securities laws. Placing a high cost on brokers' efforts to recover postliquidation inargin debts can only operate to increase the percentage of collateral required by brokers or the interest rates on margin lending. Either result inpairs margin trading and its function of increasing the liquidity of securities markets.

Since the majority of brokers' clains in this area will not reasonably be subject to legitinate securities laws defenses, the determination of whether a broker's claims are to be arbitrated or litigated must involve at least some inquiry into the substantiality of the securities laws defenses. The issue of arbitrability is too crucial to the final outcome of such disputes to allow mere allegations to control the choice of foruin. Denying arbitration of such claims because of mere allegations of securities laws defenses is not required by the Wilko doctrine of judicial enforcement of securities laws coinpliance; such a course would only serve to frustrate the purpose of the Federal Arbitration Act in an important area of commercial arbitration.

The need to inquire into the substantiality of securities laws defenses was recognized in a case arising out of a broker's claim for a postliquidation inargin debt, Shemtob v. Shearson, Hammill \& Co. ${ }^{144}$ The investors moved for a stay of a broker-initiated arbitration proceeding at the saine time they filed a complaint based on section $10(b)^{145}$ and rule $10 \mathrm{~b}-5^{146}$ of the Exchange Act. The court determined, after a factual investigation of the claim, that the investor was, at best, alleging the breach of an oral agreement relating to margin maintenance calls. Finding a lack of substantial defenses under the securities laws, the court refused to stay the arbitration proceedings; it characterized the investors' claims as nothing more than a "garden-variety customer's suit agamst a broker for breach of contract" which it would not allow to be "bootstrapped" into a securities law dispute. ${ }^{147}$ Shemtob was an unusual case in that the investors filed a complaint in addition to their inotion for a stay, thus subjecting their allegations to more scrutiny than had they filed a single motion. The court's protection of contractual

143. See SEC SPECIAL STUDY, supra note 10, ch. 12, at 561.

144. 448 F.2d 442 (2d Cir. 1971).

145. 15 U.S.C. $\& 78 \mathrm{j}(\mathrm{b})(1970)$.

146. 17 C.F.R. $\$ 240.10 b-5$ (1976).

147. 448 F.2d at 445. 
arbitration rights by a preliminary factual inquiry into the securities laws issues is nonetheless noteworthy, demonstrating that the arbitrability determination need not rely entirely on the vagaries of pleading and procedure. $^{148}$

\section{B. The Separability of Arbitrable and Nonarbitrable Claims}

Securities fraud claims are imvariably accoinpanied by common law claims of fraud, negligence, and breach of fiduciary duty-claims which are generally arbitrable. ${ }^{149}$ The problem posed by a group of arbitrable and nonarbitrable claims based on common facts has generated a variety of judicial responses. Courts are understandably reluctant to have two different tribunals hear substantially the same claims. Demial of a broker's right to arbitrate common law claims solely on the basis that they arise from the same facts as certain nonarbitrable federal claims may, however, seem to be a tortured extension of the Wilko doctrine, seriously impinging on the broker's contractual right to arbitration.

In disputes arising outside the securities industry, trial courts exercise broad discretion to preserve rights of access to commercial arbitration; claims manifestly not subject to an arbitration clause have been stayed because of their interrelationship with claims subject to a valid arbitration clause. ${ }^{150}$ In securities cases, the federal courts are more likely to retain jurisdiction over all related claims upon a finding of nonarbitrability of securities fraud claims, on the theory that the claims are "complex and intertwimed."151 The retention of all claims under court jurisdiction seems to derive from deference to the supreinacy of federal law in the area and an assumption that the pendent state law claims are merely perfunctory.

There are cases in which federal courts have segregated the claims and compelled arbitration of the pendent common law causes of action. In Macchiavelli v. Shearson, Hammill \& Co., ${ }^{152}$ a federal district court denied a motion to compel arbitration insofar as it related to claims based on rule $10 \mathrm{~b}-5$, but granted it as to all other claims (involving allegations of breach of contract, common law fraud, and Regulation $\mathrm{T}$

148. A similar factual determination was apparently undertaken in Robinson v. Bache \& Co., 227 F. Supp. 456 (S.D.N.Y. 1964); the court examined the only securities law violation alleged, determined it was groundless, and directed arbitration.

149. E.g., Pawgan v. Silverstein, 265 F. Supp. 898 (S.D.N.Y. 1967).

150. E.g., Collins Radio Co. v. Ex-Cell-O Corp., 467 F.2d 995 (8th Cir. 1972).

151. See, e.g., Seymour v. Bache \& Co., [1975-76 Transfer Binder] FED. SEc. L. REP. (CCH) II 95,402, at 99,058 (S.D.N.Y.), aff'd mem., 538 F.2d.313 (2d Cir. 1976), cert. denied, 45 U.S.L.W. 3275 (U.S. Oct. 12, 1976).

152. 384 F. Supp. 21 (E.D. Cal. 1974). 
violations) on the grounds that they were "clearly severable."153

A method of preserving the rights of both parties by segregating the arbitrable and nonarbitrable claims while avoiding duplicate proceedings was advanced in Stockwell $v$. Reynolds \& Co. ${ }^{154}$ After determining that the plaintiff's securities fraud causes of action were nonarbitrable, the federal district court directed that claims arising out of the same acts and practices, but based on common law fraud, negligence, and breach of fiduciary duty, be subinitted to arbitration; however, it simultaneously stayed the prospective arbitration until a final determination could be reached by the court on the federal securities law claims.

The approach in Stockwell is a cominendable compromise because it preserves the broker's contractual right to arbitration of arbitrable issues while recognizing that the federal securities laws claims form the gravamen of the action; the state law claims are generally pendent in a very real sense. Where the investor prevails in federal court, he will have no need to invoke the arbitration procedure for his coinmon law claims; should he lose in federal court, he must submit to the agreed arbitration procedure if he wishes to further pursue his claims.

\section{Attacks on Arbitral Awards}

Once a claim has been heard in arbitration pursuant to a court order or a voluntary subinission agreement, the issue of arbitrability is substantially foreclosed. ${ }^{155}$ The grounds for vacating an arbitrator's award are quite sparse, reflecting the policy of the Federal Arbitration Act that arbitration be a final disposition of controversies; the benefits of efficiency and economy associated with arbitral proceedings diminish as the breadth of grounds for judicial review of awards expands. The Federal Arbitration Act specifies as permissible grounds for vacating arbitrators' awards: (1) fraud, corruption, or undue means in procuring the award; (2) partiality or corruption on the part of the arbitrator; (3) misconduct by the arbitrator in refusing to permit a continuance of the hearing; (4) refusal by the arbitrator to hear pertiment evidence; and (5) action by the arbitrator in excess of his powers. ${ }^{156}$ The courts have added the failure of the arbitrator to disclose substantial dealings with one of the parties, ${ }^{157}$ and the rendering of an award in manifest disregard of the law. ${ }^{158}$

153. Id. at 31. It is unclear from the court's opinion whether the rule $10 \mathrm{~b}-5$ claims were based on different facts than were the other claims, but this seems unlikely.

154. 252 F. Supp. 215 (S.D.N.Y. 1965).

155. Cf. Moran v. Paine, Webber, Jackson \& Curtis, 389 F.2d 242 (3d Cir. 1968).

156. 9 U.S.C. $\$ 10(1970)$.

157. Commonwealth Coatings Corp. v. Continental Cas. Co., 393 U.S. 145 (1968).

158. See Wilko v. Swan, 346 U.S. 427, 436-37 (1953) (dictum). 
The intra-industry structure of exchange arbitration has prompted nany disappointed claimants to attack adverse arbitral awards on the theory that the arbitrators were biased towards the respondent brokerage firm. Although it inay be generally recognized that securities arbitrators tend to identify with the interests of the broker, ${ }^{159}$ investors' efforts to identify specific conflicts of interest as a basis for overturning the award are often quite frivolous. In Isaacson v. Hayden, Stone, Inc. ${ }^{160}$ an investor seeking review of an award argned that since the respondent firm had received loans from a stock exchange trust fund for financially troubled member firms, and since each member of the exchange-including the arbitrators-contributed to the trust fund, the arbitrators had a financial interest in the firm. Not surprisingly, the court rejected this argument, stating that the plaintiff should be on notice of the existence of substantial daily dealings annong exchange members. ${ }^{161}$ In a similar case in which a nember firm had pursued in arbitration a claim against a specialist, the Second Circuit rejected the argument that since virtually all exchange members have dealings with each specialist, the arbitration panel was necessarily biased. ${ }^{162}$ Although the courts are generally quite vigilant about conflicts of interest between arbitrators and parties to the arbitration, some more direct financial interests than regular business dealing inust be shown. ${ }^{163}$

Efforts to overturn awards on the grounds that they were rendered in manifest disregard of law encounter similar difficulties. This area is troublesome because securities arbitrators customarily render awards without opinion or reasoning. By adopting a policy of discouraging written opinions, the exchanges have insulated arbitral determinations from any sort of ineaningful judicial review. ${ }^{164}$ One commentator has severely criticized Sobel v. Hertz, Warner \& Co., ${ }^{165}$ in which the Second Circuit reversed a district court order directing securities arbitrators to supply reasons for their award:

If it is recognized that "undue means" or "manifest disregard" of law "should presumably compel vacation of the award" but no method is

159. See text accompanying notes 20-21 supra.

160. 359 F. Supp. 1050 (S.D.N.Y. 1973).

161. Id. at 1052 .

162. Garfield \& Co. v. Wiest, 432 F.2d 849 (2d Cir. 1970).

163. See Arietta v. Paine, Webber, Jackson \& Curtis, Inc., 59 Cal. App. 3d 322, 130 Cal. Rptr. 534 (2d Dist. 1976), in which the court dismissed as "the product of an overfertile imagination" the investor's charge that the two stockbrokers on a fiveperson arbitration panel had been given a message by "counsel of the securities industry" to "corrupt" and "influence" the other panel members. Id. at 328, $130 \mathrm{Cal}$. Rptr. at 537.

164. See Statement of James F. Swartz (Sept. 27, 1967), reprinted in NEW YoRK ChAMBer of Commerce, supra note 10, at 18.

165. 469 F.2d 1211 (2d Cir. 1972). 
provided for determining whether or not there has been "manifest disregard" the practical result is that an arbitrator's award will be affirmed whether there was manifest disregard of law or not. ${ }^{100}$

The Second Circuit admitted that a court faced with an unexplicated arbitral award can only speculate on the grounds for the award; the inevitable result is that the court will be able to posit grounds on which the award might conceivably have been based ${ }^{107}$ and therefore confirm the award. It is doubtful that this sort of speculation accords with the Congressional purpose in providing for judicial review in the Federal Arbitration Act.

The Second Circuit in Sobel appears to have been substantially influenced by an amicus brief in which the New York Stock Exchange threatened to refuse to hear investor claims in arbitration if its arbitrators were required to give reasons for their awards. ${ }^{108}$ Considering the efforts of member firms to force customer claims into arbitration, this might well be dismissed as an idle threat; the dire predictions about added costs and delays certainly seem highly exaggerated. ${ }^{100} \mathrm{~A}$ private dispute-resolution tribunal which seeks to avail itself of the coercive remedies provided by the Federal Arbitration Act might well be expected to comply with the provision of that Act for judicial review, including the implied requirement that there be something to review. ${ }^{170}$

\section{CoNCLUSION}

The doctrine of nonarbitrability of claims based on the federal securities laws is important to the federal system of securities regulation; the public character of securities regulation requires that investors seeking to enforce liabilities created by the securities laws be accorded an opportunity to be heard in the courts. The New York Stock Exchange began as a private club, ${ }^{171}$ and its system of arbitration

166. E. BRodSKY, Gume to SecurMTIES LITIGATION 305 (1974).

167. In Sobel, the court suggested two grounds on which the arbitrators might havc based their denial of the investor's claim: "the representations . . . may have been true when made" or the firm "may have exercised reasonable supervision over its employees and not had reason to know of their fraudulent activities." 469 F.2d at 1215 n.6.

168. See id. at 1215 n.7.

169. The volume of exchange arbitrations that proceed to award is not great. During the period 1957-61, there was an average of 24 arbitration awards handed down cach year. SEC SPECIAL STUDY, supra note 10, ch. 12, at 560. In 1966, awards were rcndered in 58 cases. Statement of James F. Swartz (Sept. 27, 1967), reprinted in NEw YORK CHAMBER OF COMMERCE, supra note 10, at 4.

170. See Wilko v. Swan, 346 U.S. 427, 440 (1953) (Frankfurter, J., dissenting). Justice Frankfurter argues that "appropriate means for judicial scrutiny must be implied, in the form of some record or opinion" in order to cnsure arbitrators' application of the securities laws.

171. See W. Douglas, Democracy and Finance 65 (J. Allen ed. 1940). 
reflects that beginning. It is inappropriate for the disposition of securities fraud claims, inatters affected with a significant public interest.

Since Wilko and its progeny have substantially stripped securities industry arbitration of its power to hear claims based on the federal securities laws, the primary function of the broker's arbitration clause is to Inislead investors who are unaware of the Wilko doctrine into concluding that they are precluded from access to the courts. The arbitration clause does not in any way indicate that much of its purported coverage is void. ${ }^{172}$ The dangers inherent in such clauses were recognized by the SEC's General Counsel in a pre-Wilko opimion:

[T] he anti-fraud provisions of the SEC statutes are violated by the employment of any legend, hedge clause, or other provision which is likely to lead an investor to believe that he has in any way waived any right of action he may have. ${ }^{173}$

The General Counsel's opinion suggests that the arbitration clause, by representing that the investor has waivcd access to the courts-a right that cannot under Wilko be waived-inay itself violate the antifraud provisions. It certainly raises questions about the practice of including such an arbitration clause in standard customer agreements.

While the courts have recently been strongly supportive of arbitration, certain areas of dispute resolution remain incompatible with the arbitration process. Though the securities industry nnay have a long tradition of arbitration, that tradition must yield to the public interest in judicial enforcement of the federal securities laws. Arbitration may be appropriate for the resolution of certain imvestor-broker disputes, but the purpose of the nonwaiver provisions is frustrated by the continued use of boilerplate arbitration clauses and the industry's apparent refusal to acquiesce in the Wilko doctrine. Until the securities industry takes its mandate of self-regulation more seriously, investors will be forced to resort to the courts for protection froin securities industry arbitration.

Robert J. Zepfel*

172. In its Code of Arbitration Procedure, the NASD has included a curious footnote to its provision for arbitration of claims against customers who have signed arbitration agreements. The note states that the provision is "not intended to conflict" with Wilko v. Swan, and that in "applicable cases" the Association will require a member to seek a determination under the Federal Arbitration Act whether the dispute is "properly arbitrable." NASD MANUAL (CCH) \3 3702.

173. See SEC Securities Act Release No. 3411 (April 10, 1951).

* B.A. 1974, University of California, Berkeley; third-year student, Boalt Hall School of Law. 